\title{
Morphological Evaluation of Gallesia Integrifolia Seedlings Under Different Water Management Systems
}

\author{
Paulo Ricardo Lima ${ }^{1}$ (1) 0000-0003-3313-0613 \\ Augustinho Borsoi ${ }^{2}$ (1) 0000-0002-1361-5464 \\ Ubirajara Contro Malavasi ${ }^{1}$ (1) 0000-0003-4300-4338 \\ Martios Ecco ${ }^{3}$ (1) 0000-0002-8885-4347 \\ Marlene de Matos Malavasi ${ }^{1}$ (D) 0000-0002-6726-6490
}

\begin{abstract}
This study aimed to quantify the effects of water management during hardening on seedlings of Gallesia integrifolia (Spreng.) Harms, evaluating leaf temperature, morphometric variables, and their performance after hardening in sandy and clayey soil. Water regimes included irrigation for four weeks (daily, every two, three, and four days). Leaf temperature was recorded at the end of each irrigation cycle. Increases in height, root collar diameter, root dry mass, and aerial part dry mass were measured at the end of the hardening period. The seedlings irrigated every two and three days did not significantly differ $(p>0.05)$ from those irrigated daily. Irrigation every four days reduced the speed of aboveground growth and increased leaf temperature. The seedlings irrigated every three and four days were more resistant to water deficit than those from other treatments, showing severe symptoms of water deficit later.
\end{abstract}

Keywords: pau-d'alho, leaf temperature, hardening.

\section{INTRODUCTION AND OBJECTIVES}

Gallesia integrifolia (Spreng.) Harms, popularly known as pau d'alho, occurs in all regions of the Brazilian Atlantic Forest, most frequently in the states of São Paulo and Paraná (Arunachalam et al., 2016). This species is recognized as having great medicinal importance (Bussmann \& Glenn, 2010), the ability to be established in degraded areas, and attractiveness to fauna (Feijó et al., 2009).

The growing demand for seedlings of native woody species in the last years shows the need to develop protocols that optimize their production at low cost and with morpho-physiological quality to meet the planting needs (Oliveira et al., 2016).

In the planting, seedlings must face the diversity of unfavorable effects to their establishment. Operational damages during handling and planting, exposure and desiccation of roots, periods of water deficiency or saturation, wind speed, and weeds are the main factors that contribute to the nonsuccessful planting of seedlings of woody species.
Drought events have been intensified in the last decades and are probably associated with climate change due to the global warming (Fritsche-Neto \& Borém, 2011). Soil water scarcity causes the plants to develop strategies to minimize physiological needs, such as transpiration and photosynthesis, to survive with minimal water loss (Taiz et al., 2017).

Hardening performed before sending seedling to planting sites refers to the set of operational practices adopted during the final phase of the production process with the purpose of increasing tolerance to soil and climatic adversities, possibly found in the planting areas. Some of these practices include manipulation of fertilization, light regime, root and aerial part pruning, and irrigation management (Jacobs \& Landis, 2009).

Infrared thermometry is an important tool to assure the quality of seedlings, besides being a simple and accessible technique. It can measure leaf temperature and contribute to the knowledge of the morpho-physiological mechanisms that allow plants to tolerate water deficit conditions.

\footnotetext{
${ }^{1}$ Universidade Estadual do Oeste do Paraná (Unioeste), Marechal Cândido Rondon, PR, Brasil

${ }^{2}$ Centro Universitário Fundação Assis Gurgacz (FAG), Cascavel, PR, Brasil

${ }^{3}$ Pontifícia Universidade Católica do Paraná (PUCPR), Toledo, PR, Brasil
} 
The severity of water deficit is probably indicated by the magnitude of the elevation in leaf temperature, which can be used as an indicator of water availability for plants (Wang et al., 2010). According to Pazzetti et al. (1993), plant canopy temperature is important to determine water deficit, based on the hypothesis that the water transpired by the leaf causes its cooling when evaporating.

The quality evaluation of seedlings is usually based on morphological aspects, basically including linear growth measurements, as they are non-destructive and easily repeatable in the nursery (Delarmelina et al., 2014). However, this assessment is insufficient, making it necessary to analyze the plant physiological characteristics (Silva, 2004).

Given the above, this study aimed to quantify the effects of water management during hardening on seedlings of $G$. integrifolia, assessing leaf temperature and morphometric variables associated with seedling quality and survival after hardening in sandy and clayey soils.

\section{MATERIALS AND METHODS}

The experiment was performed in the municipality of Marechal Cândido Rondon (Paraná, Brazil), between October 2012 and March 2013, using a protected environment consisting of a galvanized iron structure with an arc-shaped roof $(7 \times 30 \mathrm{~m}$ and $3.5 \mathrm{~m}$ high), covered by an anti-UV lowdensity polyethylene (LDPE) plastic film of $150 \mu$ m thickness, and laterally closed by a white $30 \%$ shading screen.

Seedlings of G. integrifolia (RNC: 24092) were produced by direct sowing in plugs of $120 \mathrm{~cm}^{3}$, filled with commercial substrate (Plantmax') made of pinus bark, which were placed on plastic trays with capacity for 96 plugs on benches at $1.2 \mathrm{~m}$ from the ground. The fertilization consisted of $8 \mathrm{~g}$ of controlled release fertilizer (Basacote Plus 6M), formulation $\mathrm{N}_{2}-\mathrm{P}_{2} \mathrm{O}_{5}-\mathrm{K}_{2} \mathrm{O}$ (16-8-12), per bag of $25 \mathrm{~kg}$ of substrate.

In the seedling growth phase, which lasted twenty-one weeks, irrigation was performed daily by sprinkling water until it dripped from the lower opening of the plug. Then, when the seedlings had a height of $26.0 \pm 2.6 \mathrm{~cm}$ and a diameter of $5.17 \pm 0.35 \mathrm{~mm}$, the hardening started and lasted for four weeks.

The different management systems consisted of four water regimes: daily irrigation or control (I1), irrigation every two days (I2), irrigation every three days (I3), and irrigation every four days (I4). Watering until substrate saturation was performed between 2 p.m. and 3 p.m. in 60 seedlings of each treatment. Two hundred and forty seedlings were randomly arranged in four groups of 60 seedlings to ease water management. Each seedling consisted of one replication.

The temperature and relative humidity were monitored during hardening using a digital thermo-hygrometer
(TH-439; Equitherm) and always recorded during leaf temperature reading (12 p.m. and 1 p.m.).

After four weeks of water regimes, the increase in height, root collar diameter, root dry mass, and aboveground tissues dry mass were calculated based on the data collected before establishing the experiment and on those obtained at the end of four weeks of water management. Plant height was determined by measuring the distance between the substrate and the last leaf insertion using a graduated ruler, while root collar diameter was measured just above the substrate using a caliper.

An initial sample of 12 seedlings was used to obtain the increase in dry mass. At the end of the hardening phase, the dry mass was determined in 24 seedlings per treatment by the gravimetric method, drying them in an oven with air circulation at $65^{\circ} \mathrm{C}$ for 72 hours.

The leaf limb temperature was measured with an infrared pyrometer (HOMIS; 466A) with emissivity $(\varepsilon \lambda)$ of $95 \%$, according to the manufacturer's recommendation.

Leaf temperature was obtained by touching the equipment on the leaf limb (adaxial face) at approximately $1 \mathrm{~cm}$ from the last newly expanded leaf of each seedling. The measurements were made according to the treatments, always between 12 p.m. and 1 p.m., before the beginning of the new irrigation cycle.

The data were subjected to the Lilliefors test for normality of residues distribution and the means were compared by the $\mathrm{t}$-test at $5 \%$ probability, accepting two independent levels of $\mathrm{X}$, based on the test of two independent populations means with unknown variances (Ribeiro Jr \& Melo, 2008), using SAEG 9.0 software, according to the method used by Lima et al. (2014).

The leaf temperature on the last day of each irrigation treatment was used to compare leaf temperature means with that from the control seedlings. Therefore, three comparisons were made separately: I1 (control) with I2 (fourteen readings); I1 with I3 (nine readings), and I1 with I4 (seven readings).

The survival test consisted of assessing the seedling resistance to water deficit for eight weeks using twenty seedlings randomly selected from each treatment. The seedlings were transplanted into 5-L pots, containing soil with sandy loam texture $(21.4 \%$ clay, $9.55 \%$ silt, and $69.55 \%$ sand) or with clayey texture (60.1\% clay, $32.35 \%$ silt, and $7.55 \%$ sand).

At the time of transplanting, the pots were irrigated until reaching the field capacity of each soil. The seedlings were subjected to complete water restriction until wilt symptoms appeared. All seedlings were weekly monitored, individually assessing the stress levels that affected plant survival in both soil types.

Plant responses to water deficit levels were previously defined on a I-V scale, according to Saad et al. (2009). The visual evaluations on each plant included: I - no symptoms; 
II - mild deficit (apical buds slightly wilted); III - moderate deficit (wilted plant); IV - severe deficit (plant with at least one dry leaf); and $\mathrm{V}$ - extreme deficit (completely dry leaves).

When the seedlings remained in the pots, the mean temperature in the propagation environment was $19.8^{\circ} \mathrm{C}$ and the relative air humidity was $77.6 \%$.

\section{RESULTS AND DISCUSSION}

During hardening the mean temperature in the propagation environment remained at $35.6^{\circ} \mathrm{C}$, the relative air humidity at $52 \%$, and the vapor pressure deficit (VPD) at $2.89 \mathrm{kPa}$, as shown in Figure 1. The VPD was calculated according to the method proposed by Landsberg (1986).

The analysis of the variables in seedlings subjected to treatments I1 and I2 indicated no significant differences ( $p>0.05)$. In the control seedlings (I1), height $(\mathrm{H})$, root collar diameter (RCD), root dry mass (RDM), and aboveground tissues dry mass (APDM) had increases of $3.07 \mathrm{~cm}, 0.68 \mathrm{~mm}$, $0.48 \mathrm{~g}$, and $0.47 \mathrm{~g}$, respectively. In seedlings irrigated every two days (I2), H, RCD, RDM, and APDM increased, on average, $2.79 \mathrm{~cm}, 0.70 \mathrm{~mm}, 0.45 \mathrm{~g}$, and $0.44 \mathrm{~g}$ during the hardening phase, respectively. The difference in leaf temperature values as a function of I1 and I2 water regimes was only $0.53^{\circ} \mathrm{C}(p>0.05)$.

There were no statistical differences $(p>0.05)$ between the seedlings subjected to I1 and I3 regarding the measured variables $(\mathrm{H}, \mathrm{RCD}, \mathrm{RDM}$, and $\mathrm{APDM})$, which increased, on average, $2.48 \mathrm{~cm}, 0.52 \mathrm{~mm}, 0.43 \mathrm{~g}$, and $0.15 \mathrm{~g}$, respectively. Regarding leaf temperature, the control treatment (I1) had mean temperatures of $22.83^{\circ} \mathrm{C}$ and the seedlings subjected to I3 had mean leaf temperatures of $23.92^{\circ} \mathrm{C}$, with an average increase of $1.09^{\circ} \mathrm{C}$ compared to I1, showing no statistical difference between each other $(p>0.05)$.

Seedlings subjected to I4, as shown in Figure 2, significantly differed $(p<0.05)$ from those of I1, with a reduction of $27.68 \%$ in height growth rate (Figure 2a) and $30.43 \%$ in diameter (Figure $2 \mathrm{~b}$ ). For the other morphometric variables (RDM and APDM) there were no significant differences $(p>0.05)$.

The average increases estimated during the hardening of seedlings subjected to I4 were $2.22 \mathrm{~cm}$ for $\mathrm{H}$ and $0.48 \mathrm{~mm}$ for RCD. For RDM (Figure 2c) and APDM (Figure 2d) the increase was $0.35 \mathrm{~g}$ and $0.14 \mathrm{~g}$, respectively; however, there was no difference $(p>0.05)$ compared with those found in I1. The leaf temperature of I4 seedlings significantly differed $(p<0.05)$ from those observed in I1 seedlings, with an increase of $2.48^{\circ} \mathrm{C}$ (Figure 2e).

The results indicate that the water deficit did not interfere with the assessed morphometric variables, probably because of the reduction in the initial exponential growth of the seedlings resulting from the volume of the substrate. Hardening does not aim at the development of seedlings but rather at the acclimatization to the immediate post-planting stresses (Silva et al., 2004).

Although adaptability and tolerance to water stress are intrinsic strategies of different plant species, similar results were found by Silva et al. (2004), who found no differences in height, root collar diameter, and total dry mass in seedlings of Eucalyptus grandis Hill Ex. Maiden subjected to different water management systems in the hardening phase.

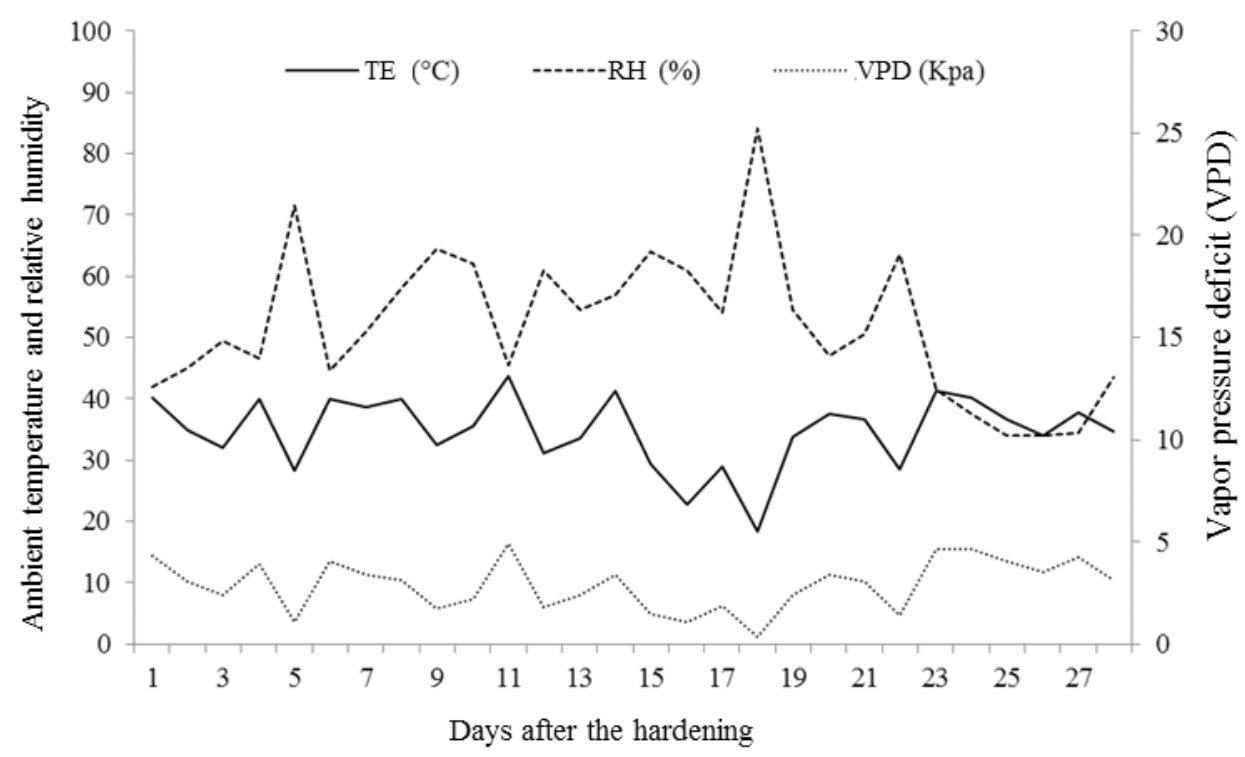

Figure 1. Mean temperature variation in the propagation environment (TE), relative humidity (RH), and vapor pressure deficit (VPD) during hardening of $G$. integrifolia seedlings. 
Scalon et al. (2011) reported that height and diameter in seedlings of Guazuma ulmifolia L. were higher when the plants were subjected to higher water availability, finding no changes in root growth. Schwider et al. (2013) reported lower root dry mass in seedlings of eucalyptus under water deficit. Lima et al. (2014) observed that severe water deficiency reduced growth and dry biomass production in seedlings of Handroanthus impetiginosus (Mart. ex DC) Mattos.
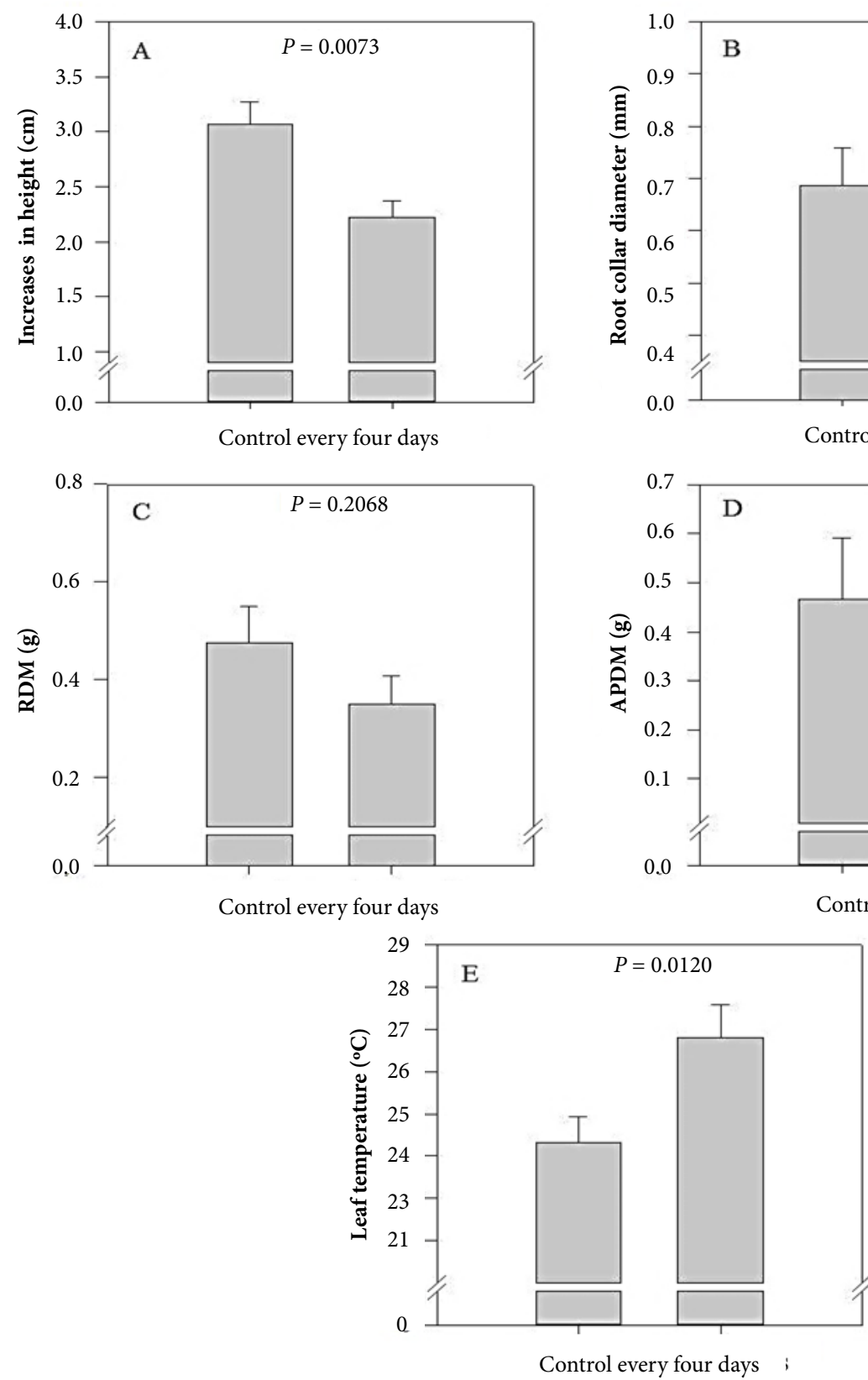

Figure 2. Increases in height (a), root collar diameter (b), root dry mass (c), aboveground dry mass (d), and leaf temperature (e) in control seedlings of $G$. integrifolia subjected to water restriction every four days during hardening.

RDM: root dry mass; APDM: aboveground dry mass. 
The results show that aboveground tissues are more affected by water restriction than root tissues, in terms of growth. According to Hsiao \& Xu (2000), when the water potential is suddenly reduced in the roots, there is a fast osmotic adjustment, resulting in a partial recovery of turgescence and consequently allowing the roots to resume the growth even at low water potential. These authors also explain that such osmotic adjustment occurs slowly in the aboveground tissues leading to the inhibition of its growth.

Regarding leaf temperature variation measured in the I1 and $\mathrm{I} 3$ seedlings, as well as between I1 and I2, there were no significant differences. However, there was an increase from 0.53 to $1.09{ }^{\circ} \mathrm{C}$ in leaf temperature, as water interruption increased from two to three days.

There was a significant difference in leaf temperature between I1 and I4 seedlings. This difference is probably because water restriction induces stomatal closure in seedlings of G. integrifolia, thus preventing water loss by stomatal transpiration, resulting in leaf heating.

Lima et al. (2014), assessing the effects of water management during hardening of Handroanthus impetiginosus seedlings, observed that plants irrigated daily had a larger increase in diameter than those irrigated every three days and that seedlings irrigated every four days had higher root growth and reduction in the aerial part growth. According to these authors, the use of infrared thermometry made the measurement of leaf temperature possible during hardening, with a gradual increase in temperature as the water stress period was prolonged.

The leaf temperature difference between plants subjected to water deficit and those under normal conditions is based on water status, stomatal behavior, and latent heat loss by transpiration, with tolerance variations depending on the species, environment, and intensity, duration, and time of the day (Moualeu-Ngangue et al., 2016).

The stomatal regulation allows gas exchange and makes possible the latent heat loss resulting from the radiation incident on the leaf (Pinheiro \& Chaves, 2011) because of the heat loss by transpiration, since the evaporation of water from the leaf occurs due to thermal energy absorption, reducing leaf temperature from 2 to $3{ }^{\circ} \mathrm{C}$ (Endres et al., 2010). On the other hand, the gradual increase in leaf temperature is a strong indicator of water stress in the substrate, since it causes the closure of the stomata to prevent higher water losses by transpiration (Pinheiro \& Chaves, 2011; Xu et al., 2010).

The increase in air temperature and consequently in VPD interferes with the transpiration until the stomatal regulation starts preventing excessive water loss and resulting in leaf heating. This behavior was reported by Silva et al. (2004), who analyzed transpiration throughout the day in seedlings of E. grandis and observed that plants subjected to water deficit "perceived" this condition and had a defensive reaction against dehydration with the fast closure of their stomata, in addition to having a lower variation in transpiration throughout the day in comparison with seedlings subjected to less stress.

Analyzing the percentage of seedlings irrigated every four days affected by water deficit, according to Table 1 no moderate and severe water deficit symptoms were observed at 7 days, respectively, in plants grown in sandy and clayey soil. The same occurred with the appearance of extreme water deficit symptom at 14 days in clayey soil.

At 21 days of complete water restriction, $100 \%$ of the studied seedlings had extreme deficit symptoms in clayey and in sandy soil, regardless of water management. Seedlings of G. integrifolia transplanted into sandy soil had extreme water deficit symptoms at 56 days. Compared with the clayey soil, there is a higher tolerance to water restriction, since there was an increase of 25 days after it was found in this soil.

The percentage of seedlings with water deficiency symptoms increased in both soil types as a function of time, as well as the severity of the symptoms, showing an influence of the restriction time, water management during hardening, and of the different types of soil.

The differences in water deficit symptoms indicated that seedlings subjected to irrigation regime every three and four days had slowly mitigated water deficit symptoms in comparison with those subjected to the other water management systems, regardless of the type of soil.

Seedlings acclimatized in the nursery under water deficit and cultivated in sandy soil may better tolerate the lack of water, or that substrate retains more water so that the symptoms manifested themselves lately. In sandy soil, the greater amount of water close to the field capacity results in less effort by the plant to absorb water, resulting in a delayed manifestation of symptoms (Carlesso \& Santos, 1999).

According to Saad et al. (2009), the availability of water close to field capacity is greater in sandy soil than in clayey soil (Saad et al., 2009). These authors found that the survival time of seedlings of Eucalyptus urograndis under irrigation management during the hardening phase was shorter in clayey soil than in sandy soil (14 days for seedlings not tolerant to water deficit and 20 days for seedlings adapted to water deficit). They also reported that in sandy soil, seedlings survived for 29 days regardless of the water acclimatization during hardening and that the water deficit symptoms appeared first in seedlings grown in clayey soil, mainly in those not adapted to water deficit. For example, between $-0.01 \mathrm{MPa}$ and $-0.03 \mathrm{MPa}$, they found a $7.4 \%$ humidity range in sandy soil and $4 \%$ in clayey soil. 


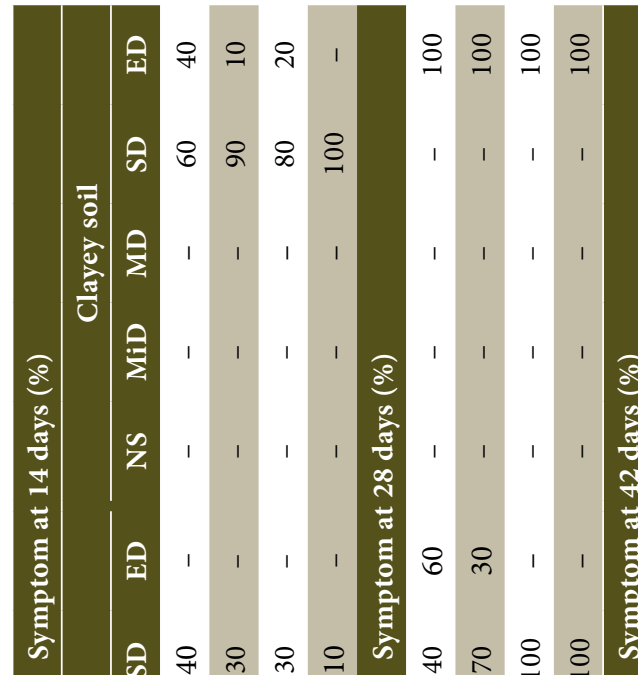

\&: \& \& $ஃ$

溇

हे 유 ᄋ

을 우우웅

Z

ஓ

อ
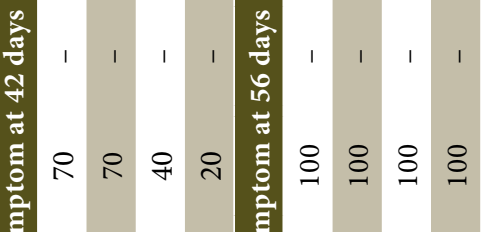

ஓ \& \& ह

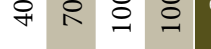

$\vec{\sim}$

$\sqrt{2}$

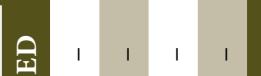

ঃ ஃ

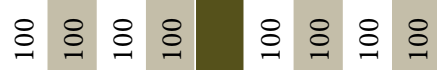

कि 아슈으.

क्ष

용 \&

ब

$1,1,-1$

Z

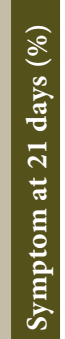

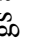

寻

$\stackrel{2}{5}$

కొ

نे

$\circ)^{\circ}$

急

峁

节

吾

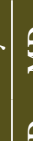

옹ㅇㅇ

을아 은으아

는아우우 8

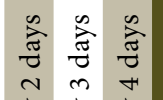

苛

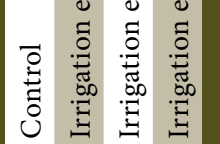

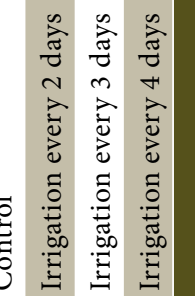
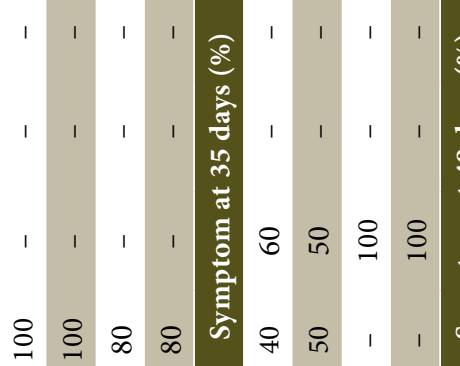

아 오

के

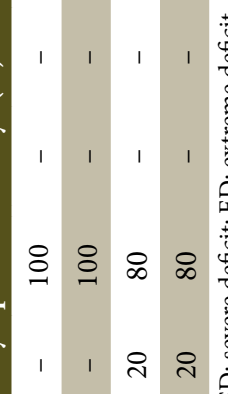

ㅇํ ㅇำ

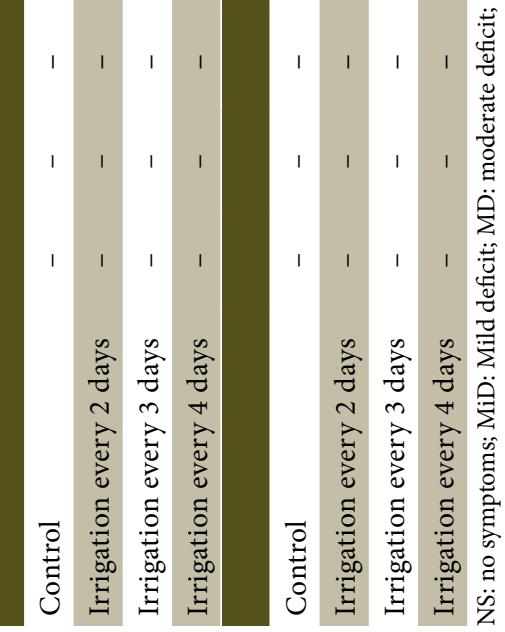


Comparing hardening effects to the results obtained in the period of water restriction, seedlings of $G$. integrifolia irrigated every three and four days had higher quality since they tolerated water deficit so that the symptoms manifested themselves later than in those subjected to the other water management systems.

In addition, water management every four days significantly reduced water use. The results obtained in this study show that water restriction management in seedlings of G. integrifolia resulted in a gradual increase in leaf temperature and the use of an infrared pyrometer may help the nurseryman to make decisions about the quality of seedlings during the hardening period.

\section{CONCLUSIONS}

Regarding water stress there was no significant difference between seedlings of G. integrifolia irrigated every two and three days and those irrigated daily (control).

Seedlings of G. integrifolia irrigated every four days during hardening had a slower aboveground growth and increased leaf temperature.

The infrared pyrometer has accuracy in the measurement of leaf temperature during the hardening phase of G. integrifolia seedlings.

The water deficit symptoms appeared first in seedlings grown in clayey soil, especially in those not acclimated to water deficit.

Seedlings irrigated every three and four days were the most resistant to water deficit, manifesting late severe symptoms.

\section{ACKNOWLEDGEMENTS}

We thank the Coordenação de Aperfeiçoamento de Pessoal de Nível Superior (Capes) and the Conselho Nacional de Desenvolvimento Científico e Tecnológico (CNPq) for supporting the research and authors.

\section{SUBMISSION STATUS}

Received: 21 Feb. 2017

Accepted: 21 Feb. 2019

Associate editor: José Henrique Tertulino Rocha

(D) 0000-0002-7471-4191

\section{CORRESPONDENCE TO}

\section{Paulo Ricardo Lima}

Universidade Estadual do Oeste do Paraná (Unioeste), Av. Castelo Branco, 641, CEP 79980-000, Mundo Novo, MS, Brasil

e-mail: paulorikardoo@hotmail.com

\section{REFERENCES}

Arunachalam K, Ascêncio SD, Soares IM, Souza Aguiar RW, Silva LI, Oliveira RG et al. Gallesia integrifolia (Spreng.) Harms: In vitro and in vivo antibacterial activities and mode of action. Journal of Ethnopharmacology 2016; 184: 128-137. 10.1016/j.jep.2016.03.005

Bussmann RW, Glenn A. Traditional Peruvian medicine for the treatment of respiratory disorders. Revista Peruana de Biologia 2010; 17(2): 331-346.

Carlesso R, Santos RF. Disponibilidade de água às plantas de milho em solos de diferentes texturas. Revista Brasileira de Ciência do Solo 1999; 23(1): 17-25. 10.1590/S0100-06831999000100003

Delarmelina WM, Caldeira MVW, Faria JCT, Gonçalves EO, Rocha RLF. Diferentes substratos para a produção de mudas de Sesbania virgata. Floresta e Ambiente 2014; 21(2): 224-233. 10.4322/floram.2014.027

Endres L, Souza JL, Teodoro L, Marroquim PMG, Santos CM, Brito JED. Gas exchange alteration caused by water deficit during the bean reproductive stage. Revista Brasileira de Engenharia Agrícola e Ambiental 2010; 14(1): 11-16. 10.1590/S1415-43662010000100002

Feijó NSA, Mielke MS, Gomes FP, França S, Lavinsky AO. Growth and photosynthetic responses of Gallesia integrifolia (Spreng.) Harms and Schinus terebinthifolius Raddi seedlings in dense shade. Agroforestry Systems 2009; 77(1): 49-58. 10.1007/s10457-008-9190-x

Fritsche-Neto R, Borém A. Melhoramento de plantas para condições de estresses abióticos. 1. ed. Visconde do Rio Branco: Suprema; 2011.

Hsiao TC, Xu LK. Sensitivity of growth of roots versus leaves to water stress: biophysical analysis and relation to water transport. Journal of Experimental Botany 2000; 51(350): 1595-1616. 10.1093/ jexbot/51.350.1595

Jacobs DF, Landis TD. Hardening. In: Dumroese RK, Luna T, Landis TD, editors. Nursery manual for native plants: A guide for tribal nurseries. v. 1. Agriculture Handbook 730. Washington: USDA, Forest Service; 2009. p. 217-227.

Landsberg JJ. Physiological ecology of forest production. London: Academic Press; 1986.

Lima PR, Horbachi MA, Dranski JAL, Ecco M, Malavasi MM, Malavasi UC. Avaliação morfofisiológica em mudas de Handroanthus impetiginosus (Mart. ex DC.) Mattos durante a rustificação. Floresta e Ambiente 2014; 21(3): 316-326. 10.1590/2179-8087.058813

Moualeu-Ngangue DP, Chen T-W, Stützel H. A modeling approach to quantify the effects of stomatal behavior and mesophyll conductance on leaf water use efficiency. Frontiers in Plant Science 2016; 7: 875. $10.3389 /$ fpls.2016.00875

Oliveira MC, Ogata RS, Andrade GA, Santos DS, Souza RM, Guimarães TG et al. Manual de viveiro e produção de mudas: espécies arbóreas nativas do Cerrado. Brasília: Rede de Sementes do Cerrado; 2016.

Oro P, Dranski JAL, Malavasi UC, Malavasi MM. Frequência da irrigação ao final da produção em mudas de espécies lenhosas. Revista de Ciências Agroveterinárias 2016; 15(2): 94-102. $10.5965 / 223811711522016094$

Pazzetti GA, Oliva MA, Lopes NF. Aplicação da termometria ao infravermelho à irrigação do feijoeiro: crescimento e produtividade. Pesquisa Agropecuária Brasileira 1993; 28(12): 1371-1377.

Pinheiro C, Chaves MM. Photosynthesis and drought: can we make metabolic connections from available data? Journal of Experimental Botany 2011; 62(3): 869-882. 10.1093/jxb/erq340 
Ribeiro Jr JI, Melo ALP. Guia prático para utilização do SAEG. Viçosa: Folha; 2008.

Saad JCC, Lopes JLW, Santos TA. Manejo hídrico em viveiro e uso de hidrogel na sobrevivência pós-plantio de Eucalyptus urograndis em dois solos diferentes. Engenharia Agrícola 2009; 29(3): 404-411. 10.1590/S0100-69162009000300007

Scalon SPQ, Mussury RM, Euzébio VLM, Kodame FM, Kissman C. Estresse hídrico no metabolismo e crescimento inicial de mudas de mutambo (Guazuma ulmifolia Lam.). Ciência Florestal 2011; 21(4): 655-662. 10.5902/198050984510

Schwider YS, Pezzopane JEM, Côrrea VB, Toledo JV, Xavier TMT. Efeito do déficit hídrico sobre o crescimento de eucalipto em diferentes condições microclimáticas. Enciclopédia Biosfera 2013; 9(16): 888-900.
Silva MR, Klar AE, Passos JR. Efeitos do manejo hídrico e da aplicação de potássio nas características morfofisiológicas de mudas de Eucalyptus grandis w. (hill ex. maiden). Irriga 2004; 9(1): 31-40. 10.15809/irriga.2004v9n1p31-40

Taiz L, Zeiger E, Moller I, Murphy A, editors. Fisiologia e desenvolvimento vegetal. 6. ed. Porto Alegre: Artmed; 2017.

Wang X, Yang W, Wheaton A, Cooley N, Moran B. Automated canopy temperature estimation via infrared thermography: a first step towards automated plant water stress monitoring. Computers and Eletronics in Agriculture 2010; 73(1): 74-83. 10.1016/j.compag.2010.04.007

$\mathrm{Xu}$ Z, Zhou G, Shimizu H. Plant responses to drought and rewatering. Plant Signaling \& Behavior 2010; 5(6): 649-654. 10.4161/ psb.5.6.11398 